\title{
MHRA
}

Modern Humanities Research Association

Between Albanian Identity and Imperial Politics: Ismail Kadare's "The Palace of Dreams" Author(s): Peter Morgan

Source: The Modern Language Review, Vol. 97, No. 2 (Apr., 2002), pp. 365-379

Published by: Modern Humanities Research Association

Stable URL: http://www.jstor.org/stable/3736866

Accessed: 03/03/2010 00:08

Your use of the JSTOR archive indicates your acceptance of JSTOR's Terms and Conditions of Use, available at http://www.jstor.org/page/info/about/policies/terms.jsp. JSTOR's Terms and Conditions of Use provides, in part, that unless you have obtained prior permission, you may not download an entire issue of a journal or multiple copies of articles, and you may use content in the JSTOR archive only for your personal, non-commercial use.

Please contact the publisher regarding any further use of this work. Publisher contact information may be obtained at http://www.jstor.org/action/showPublisher?publisherCode=mhra.

Each copy of any part of a JSTOR transmission must contain the same copyright notice that appears on the screen or printed page of such transmission.

JSTOR is a not-for-profit service that helps scholars, researchers, and students discover, use, and build upon a wide range of content in a trusted digital archive. We use information technology and tools to increase productivity and facilitate new forms of scholarship. For more information about JSTOR, please contact support@ jstor.org. 


\section{BETWEEN ALBANIAN IDENTITY AND IMPERIAL POLITICS: ISMAIL KADARE'S THE PALACE OF DREAMS}

Ismail Kadare is one of the best known of contemporary Balkan novelists and probably the only Albanian writer known widely outside his country. Among Albanian dissidents Kadare has been a controversial figure, condemned by some on account of his ambiguous relationship with the ruling party of Enver Hoxha. ${ }^{1}$ Nevertheless a recent commentator has written that 'no-one who reads The Palace of Dreams, one of Kadare's greatest works, could possibly accept the dismissive judgment of him as a party hack' (Malcolm, 'In the Palace of Nightmares,' p. 24). The novel, published in $198 \mathrm{I}$, foreshadowed the re-valorization of ethnic identity as a socio-political category that has taken place in Central and Eastern European societies since the end of Soviet-style communism. Yet it was published in 'the strictest Marxist-Leninist regime on earth - with the possible exception of North Korea', ${ }^{2}$ when 'that country was going through its most ugly and dangerous phase'. ${ }^{3}$ Despite having been translated into French in I 990 and English in I993, it has been neglected by Western critics and reviewers, who have done little more than note the power of Kadare's writing and point to the influence of Orwell. ${ }^{4}$ Kadare's language, Albanian, had virtually disappeared from global view during the post-World War Two era, and his novel belongs to an Eastern European literary tradition little known in the West. It is the aim of this article to raise the critical profile of The Palace of Dreams by showing the socio-cultural significance of material relating to littleknown Albanian and Bosnian epic traditions used by Kadare to articulate the problems of imperialistic power structures and ethnic identity during a time of political change in the Balkans. The argument falls into three parts: the first is an analysis of the significance of Bosnian and Albanian epics in the novel; the second is an interpretation of this material in terms of the implied historical setting, and the final part is a reading of the novel as a political allegory in the Albanian context of the early i 980 s.

\footnotetext{
${ }^{1}$ He has been attacked by Arshi Pipa in particular on account of his relationship with the regime of Enver Hoxha. See Arshi Pipa, 'Subversion vs Conformism: The Kadare Phenomenon', Telos, 73 (1987), pp. 47-77; Arshi Pipa, Albanian Stalinism: Ideo-Political Aspects (New York: Columbia University Press, I99o); Petar HadjiRistic, 'Shaking Albania's Torpor: Young People Feel Betrayed by Leading Writer's Departure', Index on Censorship, 20 (I99I), pp. Io-I I; Arshi Pipa, 'The Adventure of Albania's Young Turks', Telos, 92 ( 1992),pp. 99-106; Arshi Pipa, 'Conformisme et subversion: Le double jeu de Kadare', Autre Europe, 24-25 ( 1 992), pp. I 38-5I; Noel Malcolm, 'In the Palace of Nightmares', (review of Kadare's The Three-Arched Bridge), New York Review of Books, 44 (November 6, I 997), pp. 2 I-24; Stephen Schwartz, 'In the Palace of Nightmares', (letter to the editor), New York Review of Books, 45 (9 April, 1998), p. 8o; Ismail Kadare, and Noel Malcolm, " In the Palace of Nightmares": An Exchange', New York Review of Books, 45 (I 5 January, I 998), pp. 59-6o.

${ }^{2}$ Miranda Vickers and James Pettifer, Albania: From Anarchy to a Balkan Identity (London: Hurst, I 997), p. I.

${ }^{3}$ Ismail Kadare, Albanian Spring: The Anatomy of Tyranny, translated from the French by Emile Capouya (London: Saqi Books, I995), p. 8.

${ }^{4}$ Kadare is better known in the French-speaking than in the English-speaking world. See, for example, Ismail Kadaré, Le Palais des rêves, translated from the Albanian by Jusuf Vrioni (Paris: Fayard, I 99o); Ismail Kadare, The Palace of Dreams, translated from the French of Jusuf Vrioni by Barbara Bray (London: Harvill, I 993). Quotations given in the text are from this English edition unless otherwise noted.
} 
The Palace of Dreams is set in the UOS ('United Ottoman States'), an imagined Ottoman Empire late in the last century. ${ }^{5}$ The Palace itself, or Tabir Sarrail, is a vast state organization dedicated to the interpretation of the dreams of the subjects throughout the length and breadth of the Empire. All dreams are recorded, scrutinized for signs of impending social and political unrest, interpreted and classified. On the basis of the interpretations, policy is formulated by the Sultan and his powerful ministers, and the administration of the Empire is carried out. The most significant dreams are classified as Master Dreams and carry great weight in the decision-making processes. At the beginning of the novel, Kadare's protagonist, Mark-Alem, has just commenced working at the Palace of Dreams, first in selection and later providing interpretations of potential Master Dreams. The plot depends on the tension between Mark-Alem's function as an officer of the Sultan, and his position as the youngest son of an Albanian Ottoman dynasty at a time of political unrest in the Empire. Warned by his uncle, the Vizier, of the politically sensitive nature of his work at the Palace, Mark-Alem nevertheless misinterprets a crucial Master Dream, bringing about the downfall of his family. However, at the same time, he discovers in himself a hitherto unrecognized longing to reclaim his Albanian roots, which draws him to sympathize with the ethnic nationalism of his maverick uncle, Kurt. The novel ends with Mark-Alem torn between his sense of Albanian ethnicity and his blossoming career as a functionary of the Sultan's Empire.

Kadare uses the period of decadence, when 'the Turkish Empire was consumed by a slow fever', ${ }^{6}$ to represent the changing dimensions of ethno-national identity both in the provincial homelands and at the centre of the Empire. Various powerful dynasties are jockeying for influence around the Sultan in Istanbul, while in distant provinces subject peoples are becoming restive. Central to Kadare's political vision is the opposition of ethnic community and empire, rendered as a political allegory of South-Eastern (Balkan) Europe. Power is wielded through the politics of inducement, intrusion and terror, and ethnic identity exists as the repressed substratum of the 'individual' and 'social imaginary' (Castoriadis). The historical costume allows Kadare to raise questions of ethnicity and identity, and social and political allegiance at a time when the discussion of these issues was prohibited throughout socialist Central and Eastern Europe. The setting in late nineteenthcentury Istanbul bears resemblance to nothing so much as Moscow, Belgrade, Tirana, or any of the eastern bloc capitals in the last decades of the socialist era. Kadare's satiric and surreal image of the Palace is strikingly original in the literature of post-war European socialism. Like George Orwell's Ministry of Truth in Nineteen Eighty-Four, it is a powerful state institution in control of the mass unconsciousness of the Empire. However, Kadare's novel is more than a satire on the types of control typical of the Eastern European communist dictatorships. Alongside the political satire runs a second, intricately coded theme of ethnic identity at a time of decline and change in power-relationships in the Empire.

\footnotetext{
${ }^{5}$ Kadare is presumably referring to the 'Tanzimat' or 'reorganization' period of the Ottoman Empire (1839-1870) dominated by the westernizing and modernizing Turkish Ottoman grand vizier Ali Pasha (Mehmed Emin). However the description of the 'UOS' in the novel implies a much more profound level of political reorganization than actually occurred during this period.

${ }^{6}$ Ivo Andrić, The Bridge over the Drina, trans. by Lovett F. Edwards (London: Harvill, I 995), p. 94.
} 
Mark-Alem is the pampered and privileged scion of a powerful ethnic Albanian dynasty, the Quprilis, who for generations have lived in the capital of the Empire as viziers, government officials and bureaucrats in the service of the Sultan. ${ }^{7}$ The family name, Quprili, which Mark-Alem inherits through his mother's line, is a translation of the Albanian word Ura (meaning 'bridge') into the Slavic Qyprija or Kuprija. It refers to the family's original association with a 'bridge with three arches in central Albania, constructed in the days when the Albanians were still Christians and built with a man walled up in its foundations'. (The three-arched bridge possibly derives from Christian trinitarian symbolism, thus linking the Quprili family to the different historical destinies of South-Eastern Europe.) After the bridge was finished, the builder and founding ancestor of the family adopted after his first name, 'Gjon', the name of $U r a$ (bridge) 'together with the stigma of murder attached to it' (The Palace of Dreams, p. 9). The symbolism of the bridge, with its powerful associations in the Balkan literatures, ${ }^{8}$ introduces the theme of ethnicity as something deeply embedded in Mark-Alem's consciousness, a part of his individual imaginary, as well as part of the social imaginary which would manifest itself in the national uprisings of the Albanians in the late nineteenth century.

The Quprilis are a family of assimilated Ottomans, for whom power and prestige long ago took priority over ethnicity. Themes of ethnicity are present but dormant in the historical associations with the bridge, with Christianity, conversion, and assimilation into the Turkish Empire. The main symbol of Quprili power and identity is an epic poem in which the legendary deeds of the family have been preserved since the time of the Turkish occupation of the Balkans. Rhapsodists from Bosnia are invited each year to the home of the Vizier to recite passages from the ancient epic in the Bosniak language (that is, the Slav language of the Bosnian Muslims), accompanied on the single-stringed Serb gusla. ${ }^{9}$ This private annual celebration has been a source of contention between the Quprilis and the Sultan. It is said that the Sultan is jealous of their cultural eminence when he himself can command nothing more profound than the eulogies of court poets. Like the spelling of the name 'Quprili', (rather than the Turkish 'Köprülüs') the epic represents a provocation. It indicates the degree of Quprili power, prestige, and pedigree as a

\footnotetext{
${ }^{7}$ Kadare draws on the history of the Köprülüs, a prominent family of Albanian functionaries, whose name, as indicated in the novel, appears in the Larousse encyclopaedia. The entry cited by Kadare identifies Mehmed (Meth) Pasha Köprülü (I575-I66I), Grand Vizier under Sultan Mehmed I, who came from a village in Albania to found a dynasty of Ottoman grand viziers, prime ministers, admirals and generals, ministers and high ranking officials. This Albanian family was notable for its activity in the expansion of the Ottoman Empire in the Balkans and elsewhere. Kadare's Quprili family, we are told, has played a central role as 'one of the pillars of the Empire, the first to have launched the idea of its reconstruction in the form of the UOS' (The Palace of Dreams, p. 52). See Larousse du XXe Siecle en 6 Volumes (Paris: Librairie Larousse, I93 I), iv, 257. Later editions of the Larousse include shortened versions of the article. See also Barbara Jelavich, History of the Balkans, 2 vols (Cambridge: Cambridge University Press, I983), I: Eighteenth and Nineteenth Centuries, p. 81; Maximilian Lambertz, 'Die Volksepik der Albaner', Wissenschaftliche Zeitschrift der Karl Marx Universität, Leipzig, 4 (I954-55), pp. 243-89 and 439-70 (p. 270); Stavro Skendi, The Albanian National Awakening, I878-I9I2 (Princeton, NJ: Princeton University Press, I967), p. 2 I (hereafter, Skendi, National Awakening).

${ }^{8}$ Most obviously in Andrić's Bridge over the Drina, but also throughout Balkan literature. Compare Georgios A. Megas, Die Ballade von der Arta-Brücke: Eine vergleichende Untersuchung (Thessaloniki: Institute for Balkan Studies, 1976).

${ }_{9}^{9}$ The identification of languages in the novel is potentially confusing. Kadare's characters use the term 'Serb' rather than 'Bosniak', for the language of the epic from Bosnia. This Slav language is virtually identical to Serbian and is referred to variously as 'Croatian', 'Serb', and 'Bosniak'. Since the article revolves around the question of language and identity particularly in relation to the two epics, I have used the term 'Bosniak', with clarification where necessary, where Kadare, writing in the early I 980 os about events loosely situated in the late nineteenthth century, uses the term 'Serb' for the language of the epic.
} 
prominent Muslim family in the context of the interest groups and political factions around the Sultan.

At a family dinner Mark-Alem's uncle, the intellectual and playboy, Kurt, questions the role of the epic in the family's self-understanding. A heated discussion takes place, in which the Turkish occupation of Albania, the family's role in the Empire, and the ambivalence of the Albanians towards the Quprilis are raised. For the assimilated Ottoman members of the family, the Turks brought with them not slavery, but the freedom to share in the Empire:

I remember what a Jew said to me one day: 'When the Turks rushed at you brandishing spears and sabres you Albanians thought they'd come to conquer you, but in fact they were bringing you a whole Empire as a present! (p. 6o)

Hence the Albanians' attitude toward the family is seen to stem from their resentment of the Quprilis for having preferred Ottoman assimilation to ethnic identity. In their ethnic provincialism the Albanians fail to see what the Quprilis have achieved for Albania, namely the opening up of opportunities and spaces for Albanians, cramped in their tiny mountainous land: 'The Turks [...] gave us Albanians what we lacked: the wide open spaces.' One of the others points out, however, that 'like all madmen's gifts [...] it brought with it violence and bloodshed', and Kurt expands this argument: 'It's bad enough when an individual life gets caught up in the mechanisms of power - when a whole nation is drawn in it's a million times worse! [ . . . Sharing power means sharing crimes' (pp. 6o-6I).

For these members of an Ottoman Albanian family the Empire is a means of advancement, self-fulfilment and widening of options and opportunities. At the same time, their proximity to the centre of power involves them in responsibility for the political acts of the Empire, such as the oppression of individuals and of peoples, including their own. Implicit in this discussion is the question of the balance in the family between Albanian ethnic and Ottoman political identity. This issue becomes explicit when one of the brothers makes a slip of the tongue:

'Anyhow, it's the Turks who helped us to reach our true stature', said the cousin. 'And we just cursed them for it.'

'Not us - them!', said the governor.

'Sorry - yes [...] Them. The Albanians back home in Albania.'

A tense silence followed (p. 6I, my emphasis)

The English translation of Jusuf Vrioni's French is unclear, as a result of the mistranslation of the French first person plural disjunctive pronoun:

- De toute façon, ce sont les Turcs qui nous ont donné des véritables dimensions, enchaïna le cousin. Et nous les en avons maudits.

- Non, pas nous. Eux! intervint le gouverneur.

- Oui, pardon: eux, les Albanais, de là-bas.

Il s'installa un silence tendu [...]

(Kadaré, Le palais des rêves, p. 76, my emphasis)

This point revolves around self-identification. The other cousin unconsciously identifies as an Albanian with the Albanians in Albania. The governor, the most senior of the family (the Vizier is not present), is at pains to avoid any false or dangerous representations. He corrects his brother to distinguish the Quprilis as 'we', the cosmopolitan Ottoman Quprilis in the capital, from 'we', the Albanian dynasty, whose primary identification is with those 'back home'. The distinction of 
the political from the ethnic is of the utmost importance here. For the Albanians in Albania, ethnic identity is not compatible with the role in the Empire to which they are subjected. For the Quprilis, Albanian identity can include an imperial dimension, which enables them to exist at the centre of political power. They all share this sense of ethnic identity and, until this point, have not questioned it. Their Albanian identity is not inimical to the Empire. They are, after all, a family of converts to Ottoman Islam who have benefited greatly from the Empire. Some identify more strongly with it than others. Any overt allegiance to Albania, understood as something more than a point of historical origin and now a group of remote provinces of the Empire, is, or was, unthinkable. Now, however, Kurt has used the family epic to raise the question of ethnic as opposed to imperial identity. Realizing the danger of this line of thinking, his brothers warn him that such thoughts must not be allowed outside the walls of the family home. The family must present themselves publicly as Ottoman Muslims for whom Albanianness represents a secondary and unimportant identity. The Bosnian epic around which this discussion revolves both symbolizes the family's Ottoman power and preserves the memory of its Albanian origins.

Mark-Alem's memories of the epic go back to his earliest childhood when he was frightened by its bloody images and lugubrious tones. Later he is puzzled by its contradictions. The family is celebrated as a dynasty of Albanian heroes, yet the epic originates from Bosnia, not Albania, and is sung in a Slav language, Bosniak, virtually identical with Serbian:

the Quprilis lived and lorded it in the imperial capital, while people recited an epic about them in a faraway province called Bosnia in the middle of the Balkans. Why in Bosnia and not in Albania, where the Quprilis originally came from? And above all why was it sung not in Albanian but in Serbian? (p. 59)

This question leads to the heart of The Palace of Dreams, to the complex ethnic, religious, cultural and political implications of the Quprili epic, for it transpires that there is actually an Albanian version of the epic. Moreover, Kurt has invited rhapsodists from Albania to recite this version at the family celebrations in spite of the dangers involved, and against the wishes of his more circumspect brothers. In response to their cries of surprise and anger, Kurt feigns curiosity but, in fact, reiterates Mark-Alem's questions as to the contradictions inherent in the family's traditional source of identification: 'for days I've been pondering the question we've all asked so often: Why have the Slavs composed an epic in our honour, while our compatriots the Albanians don't mention us in their epic?' (p. 59). This Albanian song, unlike that of the Bosnians, does not celebrate the heroic deeds of the Quprilis. Kurt's advice to his brothers to listen to the silence of the Albanian epic on the subject of their family is indicative of his changing attitudes. He interprets it as a critical silence. For all its Ottoman prestige, the family has lost its links with the spirit of the Albanian homeland. In this discussion Kurt reveals to the others how uneasily their 'Albanianness' sits with their Ottoman identity: on the one hand they are powerful members of an Empire which oppresses other national and ethnic groups, and on the other hand they themselves are members of one of these oppressed groups. The story of the origins of the family, of the three-arched bridge with its sacrificial victim from before the Turkish occupation, 'when the Albanians were still Christians', symbolizes this problematic double identity. Ironically, it is 
Mark-Alem, the pallid and characterless employee of the Palace of Dreams who will respond powerfully to the call of Albanian ethnicity in the music of the lahuta. ${ }^{10}$

The theme of the epic thus introduces material relating to the ethnic identities of Albanians, Bosnians, and Serbs in parts of Albania and the Former Yugoslavia, in particular Kosovo. The Albanians are predominantly Muslim, having converted to Islam from Christianity during the early Ottoman period. They speak a non-Slav language and trace their cultural roots back to Roman times. The Bosnians are Muslim Slavs whose language is extremely close to Serbian and whose religious identity also was forged during the period of the Ottoman occupation. The Serbs, Christian Slavs, key aspects of whose identity were born of the opposition to Ottoman rule in the Balkans and in particular in Kosovo, also play a role in the ethnic configuration of the novel. All three groups composed epic songs using similar themes over the period of the Ottoman occupation. ${ }^{11}$

Up until the point where the Albanian version of the epic is introduced, the discussion revolves around factions and political power in relation to the Ottoman Sultan, rather than around questions of ethnic identity. With the theme of the Albanian versus the Bosnian epic, however, the matter becomes more complex. In order to understand the significance of the Albanian epic, we must delve further into the history of the heroic songs of Albania and Bosnia.

Shortly after the original publication of The Palace of Dreams, Kadare wrote the foreword to a collection of Albanian ballads and short epic poems translated into French under the auspices of the Albanian Academy of the Sciences. ${ }^{12}$ Using the researches of the German Balkan specialist Maximilian Lambertz in particular, Kadare identifies the Illyrian origins of these folk ('populaire') works which were born under the 'cold sun' of the Albanian mountains, and were suppressed in 'the long night of the Turko-Islamic occupation and by the fierce chauvinist passions of neighbouring lands' (p. 7). Kadare bases his argument on the similarity of theme with earlier Greek legends, in particular those of Orestes, Circe, and Odysseus, and refers to an 'Illyro-Albano-Greek' tradition not shared by South Slav mythology (p. 9). He compares the importance of Albanian folk poems with that of the Nibelungenlied, the Chanson de Roland and Le Cid, and describes them in a passage that is re-employed, in part literally, in Kurt's description in The Palace of Dreams ( $L e$ Palais des reves, p. 78; The Palace of Dreams, pp. 62-63).

This description gives important clues, that allow us to explicate the crucial differences between the two epics as represented in the novel. The most important of these is the Orestes theme, which Kadare mentions in his preface to the

\footnotetext{
${ }^{10} \mathrm{On}$ the psychology of ethnic identification in the figures of Kurt and Mark-Alem, and on the instrumentalization and subversion of Mark-Alem's ethnic longings, see my 'Ancient Names ... Marked by Fate: Ethnicity and the "Man without Qualities" in Ismail Kadare's Palace of Dreams', The European Legacy, 7 (2002), pp. 45-6o.

11 Compare H. T. Norris, Islam in the Balkans: Religion and Society between Europe and the Arab World (London: Hurst, I 993), pp. I38-6o; Serbocroatian Heroic Songs, collected by Milman Parry, ed. and trans. by Albert Bates Lord (Belgrade and Cambridge, MA: Serbian Academy of Sciences and Harvard University Press, 1954); Stavro Skendi, Albanian and South Slav Oral Epic Poetry, Memoirs of the American Folklore Society, 44 (Philadelphia: American Folklore Society, 1954; New York: Kraus Reprint Co., I969) (hereafter Skendi, Oral Epic Poetry).

${ }_{12}^{2}$ Chansonnier épique albanais, ed. by Qemal Haxhihasani and others, version française, ed. by Luka Kolë, foreword by Ismail Kadaré (pp. 7-ro), (Tirana: Academie des Sciences de la RPS D'Albanie, Institut de Culture Populaire, 1983). My translations used throughout.
} 
Chansonnier épique albanais. Kurt translates parts of the Albanian epic for the son of the Austrian consul who notes the similarity with the story of Orestes:

'This is the knight, Zuk, treacherously blinded by his mother and her lover, who wanders over snowy mountains on his blinded steed.' 'Blinded by his mother! My God!', exclaimed the Austrian. 'But it's like the Oresteia! Das ist die Orestiaden [sic]!'( The Palace of Dreams, p. I53)

Lambertz considers the Orestes motif to be specific to the songs of northern Albania: 'Zuk plays the most prominent role in this Lahuta-epic. [...] He is a TurkishAlbanian Orestes who murders his mother on account of her affair with the Slav, Baloz, and because she put out his eyes and those of his horse' (Lambertz, p. 248). ${ }^{13}$

Another motif that helps us to identify this material more closely is that of the figure of 'Çuperli', or 'Çypri' in the original epics. Lambertz links the figure of 'Çuperli', or 'Çypri', a vizier in the Ottoman government, to the historical Köprülü family, the model for Kadare's Quprilis. 'Çuperli' is treated as a figure of contempt in Albanian epic. He is the dupe to whom a rebellious daughter is married off, when she rejects the pashas or viziers chosen by her father, and has eyes only for her Albanian hero. ${ }^{14}$ Skendi also refers to the Köprülü family in his discussion of Milman Parry's (at that time unpublished) collection of Serbo-Croation oral poetry, where a minor character by the name of 'Cuprili' (or 'Tschuprili' in its Serb transliteration) appears (Skendi, pp. 6o-6I $).{ }^{15}$ While the Quprili family is not mentioned in this particular Albanian epic in the novel, the figure of Çuperli is a stock figure in this body of songs. When the Albanian rhapsodists arrive for the recitation, they do indeed appear to hold the Quprili family in contempt:

their bright eyes seemed to express not so much scorn as complete rejection of anything that might be offered them. The footmen had served them raki in the same kind of silver goblets as those they'd handed round to the other guests, but the Albanians merely touched them with their lips. (The Palace of Dreams, p. I 50)

For the Albanian bards the Quprilis are not the stuff of heroic legend, but, on the contrary, play minor comic roles as Ottoman sycophants and dupes.

The theme of live interment, or life-in-death, also occurs in the epic. The Albanians sing a version of the 'Ballad of the Bridge with Three Arches', also hitherto known only to the Quprilis in its Bosniak (that is, Slav) form, although it deals with the origins of their family fortune:

Mark-Alem seemed to hear the blows of the masons, building in the cold sunshine a bridge sullied with the blood of sacrifice. A bridge which would not only give the Quprili family its name, but would also mark them with its own doom. (p. I5 I)

This theme is ubiquitous in the novel and is central to the Mujo and Halil cycle, where a buried man is taunted by his live enemy to come out to battle:

Thou hast found a grave, $O$ thou, bound by the bessa!

\footnotetext{
${ }^{13}$ Lambertz, 'Die Volksepik der Albaner', p. 248. In his preface to the collection of Albanian epics, Kadare emphasizes the significance of the Orestes theme for Balkan history, implying that the Balkans are a place of ongoing blood feuds, vendettas, and traditional hatreds that neither war nor peace have been able to erase (Chansonnier Épique albanais, pp. 7-10). This motif is also to be found in the most important of modern Balkan texts, Andrić's The Bridge over the Drina, pp. $173-4$.

14 'This Çuperli, also Çupri, is an actual historical figure. He is a member of the Köprülü family. [. . .] They saved and revived the Óttoman Empire in the 17 th century. Mohammed Köprülü created internal order and left to his son a ready army [. . . In Serbian songs he is called 'Cuprili' [. . . ] after the "Köprü" (bridge) of his town of birth.' (Lambertz, 'Die Volksepik der Albaner' (p. 270), my translation.)

${ }^{15}$ Compare also Parry, Serbocroatian Heroic Songs, p. 206.
} 
'It's extremely difficult to translate,' Kurt was saying. 'Almost impossible, in fact [. . .] It's about a man trying to challenge his dead enemy to a duel on his grave,' Kurt explained [...] 'The dead man can't get up, and he struggles and groans' (pp. I 52-53)

On the basis of Kadare's own indications in the text, and using the researches of Parry and Lord (I 954), Skendi (I954), and Lambertz (I954-I955), Norris (I 993), and Megas (1976), on the epics and legends of Albania, Bosnia and the Balkans, we can thus identify this body of songs as those of northern Albania, in particular the 'Mujo and Halil' cycle, where the story of Zuk and other motifs such as the figure of Çuperli, and live interment are to be found.

It has not yet been determined whether the songs of this part of the Balkans have their origins in Albanian folk-epic from the pre-Christian and Christian eras, which was then overlaid with Islamic culture after the Ottoman Islamic conversions, as Lambertz and Kadare argue, or whether they are originally Christian Slav material that had penetrated the folk culture of the Albanians and had been subjected to Islamic influences, as has been suggested in more recent research.

Skendi demonstrates the complexity of the problem by comparing Bosnian Muslim, Albanian Muslim and other South Slav versions of material going back to the battles with the Turks in the fourteenth century and earlier. Through analysis of the terms used for the different ethnic, religious and cultural groups within and in the liminal areas of the Ottoman Empire, Skendi describes the Bosnian and Albanian self-identifications as differing in terms of the emphasis on religion versus ethnicity: 'The difference between the struggles of the two peoples is that those of the Bosnians were totally religious, those of the Albanians were primarily ethnical' (Oral Epic Poetry, p. I 25). The term 'shkja' which figures in the Mujo-Halil cycle 'means both Slav and Christian Slav, but primarily the former' (p. I 25). Regardless of the origins of this material, that is, Skendi demonstrates that religion has receded as the single primary identifier in the northern Albanian songs over the period since conversion of these tribes to Islam, in favour of a cultural identification in terms of both religion and ethnicity. In the Bosnian works religion remains paramount: '[the Albanian songs] do not have the strong Moslem colour of the Bosnian songs. The Bosnians were fanatical. In their songs they do not know of a higher aim than to fight for the din (Moslem faith) and the Sultan' (Oral Epic Poetry, p. I 25). Skendi relates this to the different interests underlying Bosnian and Albanian Islam. In Albania, he writes, Islam had been embraced primarily as a means to tax relief and the protection of the Turkish state, whereas in Bosnia it was a much more deeply religious conversion. As a result of this, the Turkish-Moslem element is attenuated in the northern Albanian songs: 'True, the kaur-s (the infidel - Christians) in the Albanian songs are the enemies of the heroes of Jutbina. [. . .] But we do not meet them very often, for the Shkje [the neighbouring Slavs-PM] take their place' (Oral Epic Poetry, pp. I 26-27). ${ }^{16}$

The Balkan epics do not of course, make use of categories of nationality, and they predate any modern national boundaries of Bosnia, Albania, Montenegro, or Serbia. They take place in parts of modern Albania, Kosovo, Krajina, and Bosnia, and feature the threshold territories between Christian and Muslim occupation. Social units are the clan, the tribe, and the people, and after the Ottoman invasions

\footnotetext{
${ }^{16}$ See also Norris, Islam in the Balkans, p. I 57, on the relationships between Albanian and Bosnian epic
} traditions. 
and conversions of numbers of Balkan peoples to Islam, religious differences override most others, so that the major categories are not, for example, Albanian (Shqip) or Serb, but Turk (meaning Ottoman Muslim, not Turk) and Kaurr, Gjaur, (Giaour, Christian) (Lambertz, p. 267). For the Christian Slav, according to Lambertz, the opposition Slav/Albanian corresponded simply to that of Christian/ Turk. The use of the Turkish and Albanian languages identified the Muslim, whether ethnic Albanian or Ottoman Turk (p. 255). However, the identification of religion with nationality of the Balkan Muslims by the Christian Slavs was a simplification of more complex ethnic and cultural issues. Among the Muslims themselves differences existed between 'Albanian' and 'Slav' - in this case 'Bosnian' - and these differences were becoming exacerbated in the era of decline of the Ottoman Empire and growth of Balkan nationalisms. These epics are also linked to the Battle of Kosovo, the main foundation myth for the national and ethnic identities of the Albanians, Bosnians, and Serbs: Mark-Alem had 'often heard his family speak of the tragic battle' (The Palace of Dreams, p. I 3o), specifically the first battle of I 389 'against all the Balkans' (p. I 29). The Battle of Kosovo in which Prince Lazar died, was commemorated by the Serbs in particular as the end of the medieval Serbian kingdom, after which the Ottoman period of subjection began (Jelavich, History of the Balkans, I, 3 I). However this battle was a 'Balkan' event in which a coalition of Serbs, Bosnians, Albanians and others opposed the invading Ottomans. The Bosnian, Albanian and other Slav versions of these events were to be coloured over time by differing religious, cultural and ethnic interests and by the extraordinary complications of Balkan history. ${ }^{17}$

It is now possible to answer Mark-Alem's question, 'why in Bosnia and not in Albania [...] why was it sung not in Albanian but in Serbian?' (p. 59). Sung in Bosniak, a Slav language, and glorifying the deeds of the Albanian Muslim Quprili family, the Quprili epic is identified with those Albanians and Slavs (Bosnians) who converted to Islam in the wake of the Ottoman conquest of the western Balkans after the Battles of Savra (1385) and Kosovo Polje (1389), and some of whom became powerful dynasties within the Ottoman Empire. Hence the Bosnian Slav epic identifies the family primarily as Ottoman and Muslim, and only secondarily as Albanian in a cultural context where this latter ethnic identification has little importance, since the significant identifications are between Turk (that is, Muslim, including converts regardless of racial or ethnic identity) and Christian. In this version of the epic, the religion and culture of western Balkan converts to Islam is the point of convergence. For the Bosnian Serbs, Muslims like the Albanians, the epic is a celebration of the origins of their Ottoman identity. The socio-religious culture of Ottoman civilization overrides ethnicity as the primary identifying factor.

The Albanian epic, with its omission of the Quprilis, other than as minor figures of ridicule, and its celebration of both religion and ethnicity, with the latter moving strongly forward in the hierarchy of 'core values', has developed differently from the Bosnian version in line with the differences between Albanian and Bosnian Islam noted by Skendi above. ${ }^{18}$ Where the Bosnians were primarily Muslims,

\footnotetext{
${ }^{17}$ Compare Stefanaq Pollo and Arben Puto, with the collaboration of Kristo Frasheri and Skënder Anamali, The History of Albania from its Origins to the Present Day (London: Routledge and Kegan Paul, I981), p. 57, and Lambertz, p. 270.

${ }^{18}$ For the terminology of 'core values' in ethnicity studies, see Jerzy Smolicz, 'Core Values and Cultural Identity', Ethnic and Racial Studies 4 (198I), pp. 75-9o.
} 
Albanian Islam was much less deeply rooted, and ethnic identifications had began to displace religious identifications, particularly in the northern Albanian cycles of Mujo and Halil on which Kadare bases his fiction. The Albanian epic, that is, in which the Quprilis do not appear, has a primarily ethnic (Albanian Muslim) focus, whereas the Bosnian Slav version, in which the family does figure, is primarily Ottoman Muslim in focus. The Bosnian song is about Muslims versus Christians, where the Albanian version is primarily about Albanians versus Turks and Slavs. The one is determined by religious difference where the other expresses ethnic identity in the process of consolidation.

The theme of the two epics thus raises complex ethnic and political questions. For Kadare, following Lambertz, the song of the Albanian rhapsodists belongs to a prior, authentic tradition, against which the Bosnian Slav version is an adoption and retelling by a different people who arrived later on the Balkan peninsula. (Chansonnier épique albanais, p. 9) Similarly Kurt, the Albanian nationalist, identifies the Albanian version of the epic as the authentic one. It is Islamic and Albanian, but recalls a pre-Islamic, pre-Christian tradition. The Bosnian version, on the other hand, has been overlaid by Slav language and customs as well as Ottoman Islamic elements.

There is thus a three-way conflict between Kurt, the Quprili family and the Sultan: Kurt represents an Albanian ethnic nationalism that is Islamic, but is also strongly aware of its pre-Islamic roots, his brothers and the Vizier represent the family's political compromise with the Ottoman Empire as Ottoman Muslims ('Balkan' rather than 'Albanian' converts to Ottoman culture and religion), and the Sultan represents the Empire, a long-standing force of occupation of the Balkans with a foreign religion and culture, an imperial capital far from the Albanian periphery, and an interest in maintaining religious and cultural order throughout the Balkans, not merely in Albania. The Quprilis with their Bosnian Slav epic appear to have betrayed Albania on several fronts: they have risen to prominence as heroes of the Ottoman occupation of the Balkans, fighting where necessary against Albanian secessionists as well as against Serbs and others, and they have adopted an epic in the Bosniak, as opposed to the Albanian, language at this time of national awakening.

The significance of the epics having been established, the argument can be taken a step further by linking this material to the fictional and historical context, namely the era of resurgence of the Balkan nations at the end of the nineteenth century. Towards the end of the novel we read that 'the war against Russia was just over', and that 'Greece had left the Empire, and the rest of the Balkans was in turmoil' (p. 188). The war against the Russians can only be the Russo-Turkish war of mid I 877 , formally ending with the Treaty of San Stefano, signed in January I 878 . As a result of the agreements of the Congress of Berlin in 1878 , the Ottoman Empire retained power over Albania, Macedonia, and the eastern part of Thrace including the capital, Istanbul. Romania, Serbia, and Montenegro had been declared independent, and it was far from inconceivable that the Ottomans would lose control over the remaining Balkan possessions. Mark-Alem's first file of dreams for sorting is dated ig October. On the day in which he reviews the fateful dream of the lahuta and the bridge (which signals to the Sultan subversive developments among the Quprili family), he reads another dream dated i 8 December, presumably of the 
year 1877 . The fictive period of the novel thus begins in the winter of $1877-1878$ and ends in the spring of 1878 .

By this time in history a powerful Albanian national movement had taken shape partly in response, ironically, to the Ottoman failure to protect the interests of this largely Muslim subject nation after the Treaty of San Stefano, in which Albanianinhabited territory was assigned to Serbia, Montenegro, and the Bulgarian provinces. ${ }^{19}$ However, the uniqueness of the Albanian situation lay in the fact that a large part of the Albanian elite (as represented by the Quprili family in the novel) was integrated into Ottoman state and military structures. This was not the case among the Serbs or Bulgarians, and it hampered the attempts of Albanian nationalists to forge a state identity around which Albanian cultural identity could crystallize.

In summer 1878 , a conference of Albanian nationalists was held and permanent headquarters established in Prizren. The Ottoman government was willing to support this organization as long as the representatives identified as Ottomans (that is, Muslims) rather than Albanians (that is, ethnic nationalists regardless of religion). The situation oscillated between hardline nationalists seeking Albanian unification, autonomy, and the use of Albanian language in education and government, and those willing to accept semi-autonomy from central Ottoman government. In early I 88I the Ottoman armies were brought in to defeat the nationalist resistance and restore centralized authority. Even after this national insurrection, however, the Ottomans continued to regard the Albanians as more closely linked to them on the basis of religion and tradition, than the Serbs, Croats, and other Balkan Christian national and ethnic groups. Nevertheless, the seeds of Albanian political nationalism had been sown. ${ }^{20}$

The Albanian uprising followed the pattern of Herderian nationalism, basing itself on language and folk-culture and led by intellectuals who collected, selected, and moulded this material in line with national aspirations. During this period, Albanian intellectuals such as Zef Jubani and Thimi Mitko published collections of Albanian heroic songs in order to propagate the idea that what bound the Albanians together was 'common blood, language, customs, and common aspirations', which led Albanians to love their country and countrymen, even if they belonged to other religions (Skendi, National Awakening, pp. I 2 I-22). This latter point is important, since it indicates a shift towards a primary ethnic identification in terms of 'Albanianness' understood as a link with Albania through 'blood', language and culture, and away from primary allegiances in terms of religion and/or Ottoman identity. The glorification of Scanderbeg as the national hero of the Albanians epitomizes this shift from religion to ethnicity. The Moslem Albanians ignored the fact that Scanderbeg was a Christian fighting against the Ottomans. What mattered was that he was an ethnic Albanian who had fought for the liberation of the country: 'he was made a symbol of unification and became a national hero' (Skendi, National Awakening, p. 1 23).

\footnotetext{
${ }^{19}$ Compare Barbara Jelavich, The Ottoman Empire, the Great Powers, and the Straits Question $1870-1887$ (Bloomington: Indiana University Press, I973), pp. I I I-I6; Jelavich, History of the Balkans, I, 36 I, 363, and Skendi, National Awakening, pp. 3 I-I 10.

${ }^{20}$ See Jelavich, History of the Balkans, I, 365, and Ir: Twentieth Century, pp. 84-89, and Skendi, National Awakening, pp. 3 I-I I 0 .
} 
For the Albanians experiencing a national awakening on the western perimeter of Kadare's crumbling Empire, this powerful family with its Bosnian epic is scarcely a subject for national glorification. Ethnic and quasi-national identity is, or has become, the central issue. For them the Quprilis are turncoats whose feats are likely to be seen as betrayal of the national cause, rather than as the embodiment of Albanian heroic values. The novel is set at the time of growth of Albanian nationalism in the wake of the other Balkan nationalist movements, a time when the new nations were seeking ancient pedigrees in language, myth and folk poetry. The imagery of live burial which appears at important points in the novel, in the foundation myth of the Quprili family and again in the Albanian ballad described at the climax of the political intrigue, suggests that the issue here is the revival of Albanian identity in the 1870 os after a long period of suppression and repression by a powerful occupying force.

The friction between the Sultan and the Quprili family over the Bosnian epic revolves around questions of factional power and politics in the capital. Kurt's brothers warn that any sign of interest in the Albanian epic could be interpreted by the Sultan as a political manoeuvre in the context of the unrest in Albania and with the Austrians sitting in the western wings of the Empire. They are concerned that the family's Albanian origins might be used against it in this period of imperial instability. The Albanian epic in fact, however, introduces a deeper level of threat and danger to the family. It signals a turn within towards ethnic rather than political identifications, with their ethnic homeland rather than with their political masters. And it introduces a new factor into the power-politics of the Empire, one of which the brothers are only dimly aware, namely the issue of ethnic nationalism, ultimately of separatism. The Bosnian epic, representing the converted peoples of the Balkans who had identified primarily with their Ottoman masters, is displaced in favour of the Albanian epic, in which 'blood' and the ethnic homeland are given primacy over dynastic identity.

Moreover, the Austrians have an interest in Kurt's new-found ethnicity. Kurt's alliance with the Austrian ambassador is seen by the Sultan to indicate a destabilizing and subversive activity on the western periphery of the Empire, against which he, the Sultan, moves eastwards towards rapprochement with Russia in order to secure his regions against Habsburg intervention. This reflects the alliances and strategic positionings that were occurring in the east and west of the Ottoman Empire in the last decades of the nineteenth century. In this period of political tension the Quprili family's interest in the Albanian version of the epic signals a shift in balance. This non-Slav version is politically loaded towards the Habsburgs on the western border of the Empire, who support the non-Slav peoples of the UOS, whereas the Russians support the Slav peoples and favour the Bosnian (that is, Slav) version of the epic:

This is not just a matter of poetry and song, [. . . in fact it's an exceedingly complex business, to do with settlements and transfers of population in the Balkans, and the relations between Slav peoples and non-Slav peoples, like the Albanians. In short, it directly concerns the whole map of the Balkans. [...] Austria supports the non-Slav peoples, whereas the Slavs' 'little father', the Tsar, is always on at our Sultan about the way the people of his race are treated. $[\ldots]$ this epic deals precisely with the relations between the peoples of the Balkans. (The Palace of Dreams, p. I67) 
It is indicative of the political state of the Empire that the Sultan is moved to seek Russian support against the threat of the Habsburgs at a time when Panslavism was becoming a powerful force (See Jelavich, History of the Balkans, I, 353). For the Ottomans religion remained paramount above ethnicity and language. Among the Orthodox peoples of the Balkans, religion remained a strong linking factor, especially in opposition to the Ottomans. For the Albanians who were predominantly Muslim by the end of the eighteenth century, as for the other ethnic groups of the Balkans, ethnicity, 'blood' and native language were moving to the fore in determining group identity by the late nineteenth century. However for the Albanian (and Bosnian) Muslims, religion remained a strong link to the Ottomans which was absent in the Christian ethnic and national movements. The Quprilis are caught among these changing political, national and ethnic signifiers in the late Ottoman Empire. In the context of dismemberment of the Empire and creation of ethnic nation states, the Quprili family would be acceptable in neither camp: neither that of the Turkish majority, nor that of the newly liberated Albanians. ${ }^{21}$

It is striking that Kadare raised the ethnic question at the beginning of the I98os, when Albania was at its isolationist peak, and socialism was still firmly in place throughout Eastern Europe (See Kadare, Albanian Spring, pp. I 22-23). During the early post-war period in Eastern Europe, regardless of the brand of communism, expressions of national and ethnic identity were prohibited or at least strictly controlled. In Marxist-Leninist theory, ethnic identity could be remembered, perhaps, as a relic of the bourgeois or fascist past, and nation-states were retained as a necessity in the transitional phase of 'real-existing socialism'. Neither was relevant to the future of communism. Yet by the mid-1980s it was becoming clear that ethnicity had not simply disappeared. Feelings of ethno-national identity had not been supplanted by the unity of workers of the world, or even the brotherhood of nations. Some communist leaders manipulated elements of nationalism in order to strengthen their regime's legitimacy and popularity. More importantly, ethnicity as a liberationist category, implying a deeper and less tangible sense of belonging than merely participating in a communist nation-state, was making a come-back. ${ }^{22}$

Kadare's novel clearly functions at one level as a political allegory about the relationships between ethnic identity and centralized political power in socialist Eastern Europe. However it would be a mistake to read this novel simply as an attack on Soviet socialism, where the centre of the Empire is read as Moscow and the Quprilis as caught between the supra-national state with its uniting faith and the renascent politics of ethnicity. In his memoir, Albanian Spring, Kadare refers to The Palace of Dreams as 'the novel which launched the most ferocious attack on the

${ }^{21}$ This is, of course, what happened to the Ottoman Empire over the first decades of the twentieth century. With his modernized United Ottoman States in which the Quprilis have played an important role, Kadare implies differences between his fiction and history, which strengthens the allegorical reference to the post-war USSR.

${ }^{22}$ On the role of ethnic politics in the disintegration of the Soviet Union, see The Nationalities Question in the Soviet Union, ed. by Graham Smith (London: Longman, I 99o); Victor Zaslavsky, 'Nationalism and Democratic Transition in Postcommunist Societies', Daedalus, I 2 I (1992), pp. 97- I 22; Nadia Diuk, and Adrian Karatnycky, New Nations Rising. The Fall of the Soviets and the Challenge of Independence (New York: Wiley, I 993); Ronald Grigor Suny, The Revenge of the Past: Nationalism, Revolution and the Collapse of the Soviet Union (Stanford: Stanford University Press, I 993); Ben Fowkes, The Disintegration of the Soviet Union: A Study in the Rise and Triumph of Nationalism (New York: St Martin's Press, I 997); George Schöpflin, 'Nationalism and Ethnicity in Europe, East and West', in Nationalism and Nationalities in the New Europe, ed. by Charles A. Kupchan (Ithaca: Cornell University Press, I 995), pp. 52-65. 
dictatorship' (p. 8). Enver Hoxha in Albania combined isolationist nationalism with hard-line communism after his breaks with Belgrade (1948), Moscow (I96r), and Peking ( I 978). Hoxha's opposition to Khrushchev's revisionism and break with the Soviet Union in particular introduced a period of political and cultural isolationism in the I96os. This isolationism expressed itself both in Hoxha's state-sponsored patriotism and in a broadening of the literary horizon among writers and intellectuals. However Hoxha did not tolerate this liberalism for long. His was not a liberationist politics of ethnic identity, that is, a politics of popular democratic selfidentification as Albanian. ${ }^{23}$ Only those aspects of Albanian culture that suited his political vision were granted legitimacy. ${ }^{24}$ Albania was a nation-state, but one in which core components of Albanian culture, those of religion, historical consciousness, and ethnic customs, were rigidly controlled and, where necessary, suppressed..$^{25}$ Kadare's novel, with its awareness of ethnicity and culture as deeply embedded aspects of Albanian identity, is as much an attack on Hoxha's Albania as on Soviet power. Moscow and Tirana are both seats of totalitarian power in conflict with the ethnic self-determination of peoples in the post-war era.

More recently, in the post-communist environment of I99o, Kadare has voiced his fears of Serb expansionism: 'I wanted to remind Balkan, and in particular Serbian, writers that no people can have a peaceful conscience when it oppresses another people. ${ }^{26}$ As we have seen in his foreword to the Chansonnier épique albanais, Kadare considers Albanian traditions to be deeply rooted in the 'Illyrian-Balkan' culture that predated Slav influence. Albania is an original minor culture whose destiny has been marked by its geographical position 'at the crossroads of history between the West and the East, but it has assimilated and included the influences of the three great cultures which have passed through it': ${ }^{27}$

The Albanians are, along with the Greeks, the oldest Balkan nation. One has to understand, that this nation, which has survived the tyranny of three empires - the Roman, the Byzantine and the Ottoman - rejects the chauvinism of the Serbs. This Serbian chauvinism is the chauvinism of new-comers. It is full of inferiority complexes and morbid jealousies. It attempts the impossible: to force the Albanians to forget their culture, their history and their freedom. (Quoted in Haroche, p. 7 II, my translation)

In the context of the early I980s, Kadare's political allegory has a particular resonance. ${ }^{28}$ In I 98 I ethnic Albanians staged mass protests to demand independent republic status for Kosovo on the basis of its predominantly Albanian population, and even unification with Albania (Malcolm, Kosovo, p. 334). The dilemma of the Quprilis, caught between nascent Albanian nationalism and their traditional role as functionaries of the Empire, has clear relevance to those ethnic Albanians from

\footnotetext{
${ }^{23}$ Com $\rightarrow$ Robert Elsie, 'Evolution and Revolution in Modern Albanian Literature', World Literature Today, 65 (1991), 256-63 (p. 258).

24 "For Hoxha everything pertaining to the life of the Albanian people had to be "home-grown"; it could not be imported from abroad. "Genuine culture", he maintained, "cannot be truly so if it is not part of the blood and flesh of the people who create it and use it, if it is not conceived in their history, life, struggle and interests" ', Vickers and Pettifer, pp. I I 8- I9.

${ }^{25}$ Compare Robert Elsie, p. 259, Kadare, Albanian Spring, p. 1 22, and Pipa, 'The Adventure of Albania's Young Turks', p. 99.

${ }^{26}$ Quoted in Charles Haroche, 'Gespräch mit Ismail Kadare', Sinn und Form 42 (1990), 706-1 4 (p. 7 I 3), my translation.

${ }^{27}$ Quoted in Pipa, 'Subversion vs Conformism: The Kadare Phenomenon', p. 72.

${ }^{28}$ The most comprehensive discussion of this question is to be found in Noel Malcolm, Kosovo: A Short History (London: Macmillan, I998), pp. 3 1 4-56.
} 
Kosovo who had also identified in terms of the ideology of Yugoslav communism with its centre in Belgrade. For the Albanian rhapsodists, the Quprili family have sold out not only to the Ottomans but also to the Slavs in identifying through a Balkan Slav culture and language (the Bosnian epic). They have thus betrayed the primacy and authenticity of Albanian language and culture. Kadare is signalling his awareness of the developments whereby ethnic Albanians in Yugoslavia would be obliged to choose between ethnicity and political ideology.

Cognizant of the threat of Serb expansionism in the post-communist environment, Kadare does not himself revert to chauvinistic nationalism. His plea for Albanian identity is for self-determination in ethnic and cultural terms against what is perceived to be a stronger and potentially imperialistic power. Speaking in I990, in the wake of the events in Kosovo in 1988, his fears and warnings cannot be considered unfounded, especially given the subsequent history of the break-up of the Soviet Union and of Yugoslavia during the I99os, and of the events in Kosovo at the end of the decade.

In 1945 Ivo Andrić pessimistically acknowledged the substratum of ethnic hatreds in the Balkans:

that dark background of consciousness where live and ferment the basic feelings and indestructible beliefs of individual races, faiths and castes, which, to all appearances dead and buried, are preparing for later, far-off times unsuspected changes and catastrophes without which, it seems, peoples cannot exist and above all the peoples of this land. (Andric, Bridge over the Drina, pp. I73-4)

Ismail Kadare is not blind to the dangers of ethnic primordialism. However in this novel, written in a period when socialist structures seemed permanently fixed, he represents ethnicity as a force of individual and group identity, a part of the individual and social imaginary capable of subverting immense power-structures. The key to Kadare's political vision lies in the histories and cultures encoded in the Bosnian and Albanian epics in his novel. The Albanian epic is located at the symbolic centre, foregrounding the theme of Albanian over Ottoman, and ethnic over imperial, identity in a period of political change. The Palace of Dreams thus integrates the ethnic question into the political novel of socialist Eastern Europe. Where Orwell and other earlier critics of totalitarianism focused on aspects of individual desire as inimical to dictatorial control, Kadare showed prescience in identifying ethnic identity as a destabilizing force in communist dictatorships and as a resurgent political force at the end of the post-war era. ${ }^{29}$

University of Western Australia

Peter Morgan

\footnotetext{
${ }^{29}$ I should like to thank the Alexander von Humboldt Foundation and the University of Western Australia for funding the research on ethnicity and national identity used in this article. My thanks also go to colleagues who have read and commented on the essay, in particular Professor Leslie Bodi and Ms Kati Tonkin
} 